\section{Microbiological, rheological and physical-chemical characteris- tics of bovine meat subjected to a prolonged ageing period}

\author{
Giorgio Smaldone, ${ }^{1}$ Raffaele Marrone, ${ }^{2}$ \\ Lucia Vollano, ${ }^{2}$ \\ Maria Francesca Peruzy, ${ }^{2}$ \\ Carmela Maria Assunta Barone, ${ }^{1}$ \\ Rosa Luisa Ambrosio, ${ }^{2}$ Aniello Anastasio ${ }^{2}$ \\ ${ }^{1}$ Department of Agricultural Sciences, \\ ${ }^{2}$ Department of Veterinary Medicine and \\ Animal Production, Unit of Food \\ Hygiene, University of Naples, Federico \\ II, Italy
}

\begin{abstract}
The aim of this study was to evaluate the effects of a long ageing period on the microbiological, rheological and physicalchemical characteristics of bovine beef. For the trial n. 3 Marchigiana bovine breed (live weight of $760 \mathrm{~kg}$ approximately), slaughtered at 34 months were chosen and the loin muscles were undergone to a prolonged ageing process. The analytical determinations performed were: $\mathrm{pH}$ and $\mathrm{a}_{\mathrm{w}}$ values, texture profile analysis, Warner-Bratzler shear force, colour (CIE L*a*b*), centesimal analysis, total bacterial count, Enterobacteriaceae, Listeria monocytogenes, yeasts and moulds. The results indicate that extended ageing has a negative effect on weight loss but, by the means of the standardization of dry aging parameters, reduce lipid oxidation and improve tenderness.
\end{abstract}

\section{Introduction}

The consumer meat quality perception plays an important role in the marketing and important sensory attributes are taste, tenderness, juiciness, freshness, leanness, healthiness and nutrition (Grunert et al., 2004) that are mostly influenced by breed, sex and age. These parameters are also correlated to techniques of handling, feeding, slaughtering and period of refrigerationageing post mortem.

The influence of ageing on beef quality in terms of tenderness is considered the most important trait affecting consumer beef-eating satisfaction (Beermann, 2009). Effects of ageing on beef tenderness have been well-documented (Bratcher et al., 2005; Colle et al., 2015; Dixon et al., 2012; Eilers, et al., 1996; Gruber et al., 2006). It is indeed demonstrated that ageing increase beef tenderness because of the decrease of shear force values during post-mortem storage (Field et al., 1971; Jennings et al., 1978) as a result of the calpains myofibrillar proteolysis (Koohmarie, 1996). Dry ageing is one of the ageing techniques commonly used where unpacked meat is exposed directly to controlled environmental conditions (temperature, humidity and ventilation).

Dry-aged beef show a particular taste and flavour; however, this process is expensive because of high drying up, weight loss, possible high bacterial load and economic investment in terms of equipment and space (Parrish et al., 1991). However, consumers would be willing to pay more the ageing beef meat once familiarized with its peculiar rheological characteristics (De Geer et al., 2009).

Most research (Lepper-Blilie et al., 2012; Perry, 2012) on beef tenderness has focused on the effects of relatively shortterm ageing (80 days or less); the effects of extended ageing on tenderness, colour and on other features of beef meat have not yet been investigated.

The aim of the work is the evaluation of the effect of a long ageing period (290 days) on the microbiological, rheological and physical-chemical characteristics of bovine beef

\section{Materials and Methods}

\section{Sampling}

For the trial n. 3 Marchigiana bovine breed, slaughtered in an EU authorized slaughterhouse at 34 months and live weight of approximately $760 \mathrm{~kg}$ were chosen. The half-carcasses were cold stored $\left(0 \pm 3^{\circ} \mathrm{C}\right)$ for five days and then the sirloin steak muscles (SSM) from both sides of the animal was removed. Subsequently the SSM were placed during the period of dry ageing in a forced ventilation cell with an automatic extraction system set at a temperature of $0^{\circ} \mathrm{C}$ and at $\mathrm{HR}$ values ranging between 68 and $70 \%$. The back wall of the ageing cell was characterized by a particular coating represented by rock salt tiles (Pink Hymalaya Salt) of about $2 \mathrm{~cm}$ deep. The analytical determinations, performed in Food Chemistry and Food Microbiology laboratories of the Department of Veterinary Medicine and Animal Productions of the University of Naples Federico II, were performed on SSM at T0 (13 days post slaughter (dPS)), T1 (36dPS), T2 (110-dPS), T3 (170-dPS) and T4 (290-dPS). WBSF test was performed in
Correspondence: Maria Francesca Peruzy, Department of Veterinary Medicine and Animal Production, University of Naples Federico II, via Delpino 1, 80137, Naples, Italy.

Tel.: +39.081.2536084

E-mail: mariafrancesca.peruzy@gmail.com

Key words: ageing process, texture, meat maturation, tenderness.

Acknowledgements: the authors would thank Mr. Gerardo Buono and Mr. Michele Sgamato of "La Fattoria del Campiglione" who provided expertise that greatly assisted the research.

Contributions: GS, AA and RM designed the overall study. GS and LV performed al chemical and rheological determination. MFP and RLA performed microbiological analysis $\mathrm{RM}, \mathrm{CMAB}$ and GS analysed the results and drafted the paper. RM, MFP and AA contributed to the ideas behind the study and the writing of the paper.

Conflict of interest: the authors declare no potential conflict of interest

Funding: none.

Received for publication: 8 February 2019. Accepted for publication: 9 July 2019

This work is licensed under a Creative Commons Attribution-NonCommercial 4.0 International License (CC BY-NC 4.0).

(C) Copyright: the Author(s), 2019

Licensee PAGEPress, Italy

Italian Journal of Food Safety 2019; 8:8100

doi:10.4081/ijfs.2019.8100

Animal Science laboratory of Department of Agricultural Science of the University of Naples Federico II. From each SSM 3.00 $\mathrm{cm}$-thick steaks were aseptically removed each time of sampling.

\section{Physical-chemical analyses}

Physical-chemical analyses were evaluated by: $\mathrm{pH}$, measured with a digital $\mathrm{pH}-$ meter (Crison-Micro TT 2022, Crison Instruments, Barcelona), $\mathrm{a}_{\mathrm{w}}$ (Aqualab $4 \mathrm{TE}$ Decagon Devices Inc., USA), Moisture (\%) determined by oven drying for 24-h at $105^{\circ} \mathrm{C}$ (AOAC, 1990). Fat alteration index was evaluated by Thiobarbituric acid test (AOAC, 2000).

For the determination of nutritional value and for labelling purpose, according to Reg. EU 1169/11, total fat content, total saturated fat, salt content $(\% \mathrm{NaCl})$, sugars, carbohydrates, proteins and energy were determined (AOAC, 2000). All tests were done on $\mathrm{n} .3$ different samples in duplicate. 


\section{Microbiological analyses}

Ten grams of each sample and $90 \mathrm{~mL}$ $(1: 10(\mathrm{~W} / \mathrm{W}))$ of sterilized Peptone Water (PW, CM0009, OXOID, Basingstoke, UK) were placed in a sterile stomacher bag and homogenized for three minutes at $230 \mathrm{rpm}$ using a peristaltic homogenizer (BagMixer ${ }^{\circledR} 400$ P, Interscience, Saint Nom, France).

Subsequently, ten-fold serial dilutions of each homogenate were prepared in PW, followed by streaking in duplicate for total bacterial counts (TBC) performed according to ISO 4833-2:2013 on Plate Count Agar (PCA; CM0325, Oxoid) incubated at $30^{\circ} \mathrm{C}$ for $48 / 72-\mathrm{h}$ and for the count of the Enterobacteriaceae (EB) performed according to ISO 21528-2:2017 on Violet Red Bile Glucose Agar (VRBG, CM1082, Oxoid) incubated at $37^{\circ} \mathrm{C}$ for $24-\mathrm{h}$. The enumeration of yeasts and moulds was performed according to ISO 21527-1 on Dichloran Rose-Bengal Chloramphenicol Agar (DRBC, CM0727, Oxoid) incubated at $25^{\circ} \mathrm{C}$ for $120 / 168$-hours.

The isolation of L. monocytogenes was performed using the microbiological isolation methods ISO 11290-1:2017. In brief, 25 grams portions of each sample were homogenized into $225 \mathrm{ml}(1: 10(\mathrm{~W} / \mathrm{W}))$ of Half Fraser broth (HF, CM1053, Oxoid) and incubated at $30^{\circ} \mathrm{C}$ for $24-\mathrm{h}$. Subsequently, a loopful of the enrichment both was transferred to the surface of ALOA and PAL$\mathrm{CAM}$ plates and incubated at $37^{\circ} \mathrm{C}$ for $24-\mathrm{h}$. Moreover, $0.1 \mathrm{ml}$ of the Half Fraser broth was also transferred to $10 \mathrm{ml}$ of Fraser broth and incubated at $37^{\circ} \mathrm{C}$ for 24/48-h. Afterward, the subculture of Fraser broth was transferred in PALCAM and ALOA medium and incubated at $37^{\circ} \mathrm{C}$ for $24 / 48-\mathrm{h}$. To confirm the presence of L. monocytogenes, morphological, physiological and biochemical test were carried out.

\section{Rheological analysis}

On all samples were determined: a) Texture Profile Analysis (TPA) that measures the compression force developed by the texturometer (Shimadzu EZ test) when compressing a piece of meat (Ruiz de Huidobro, 2003). A cylindrical $10 \mathrm{~mm}$ diameter probe of ebonite was used for all TPA tests in this study.; b) Warner-Bratzler shear force (WBSF), that measures the force necessary to shear a piece of meat (1.27 cm of diameter) was determined using a Instron universal testing machine (Model 4201; Instron, Corp., Canton, MA ) with a $50 \mathrm{~kg}$ compression load cell operating at a crosshead speed of $250 \mathrm{~mm} / \mathrm{min}$. The parameter recorded was the maximum shear force which is the maximum resistance of the sample to shearing (Xiong et al., 2006);

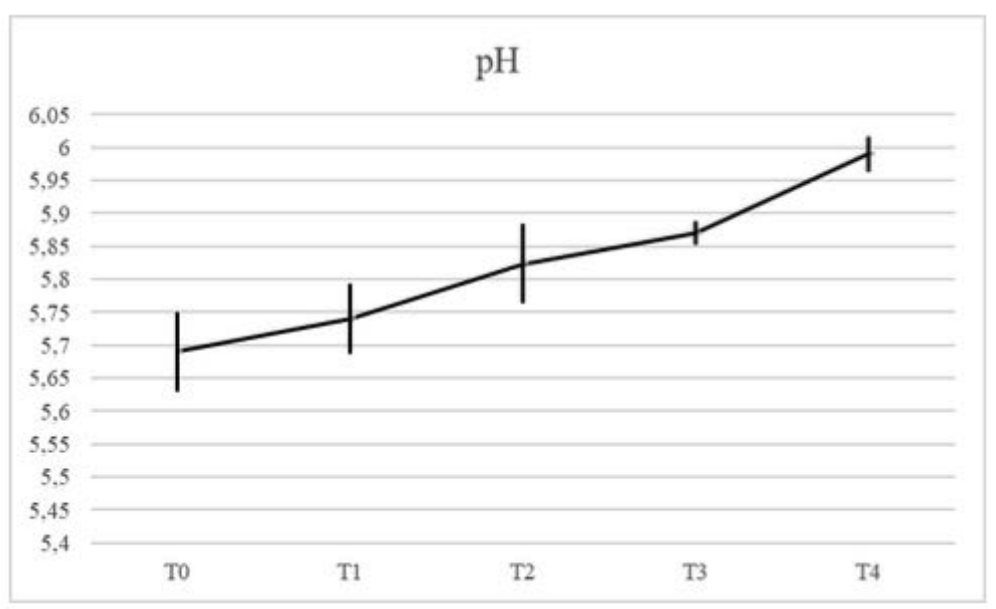

Figure 1. Trend of $\mathrm{pH}$ of the meat samples during ageing process (average $\pm \mathrm{SD}$ ).

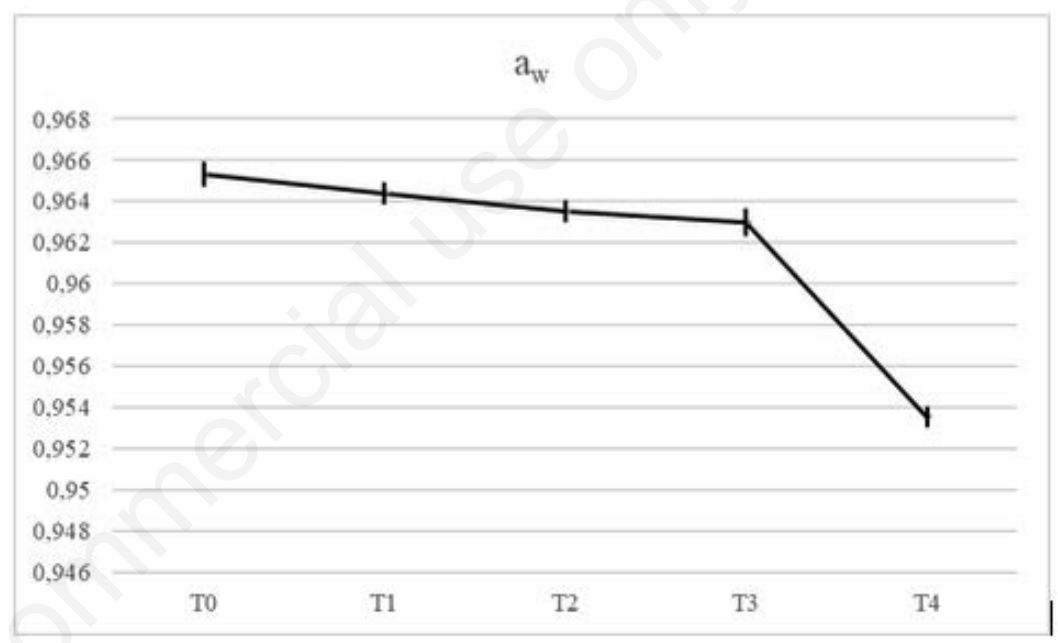

Figure 2. Trend of aw of the meat samples during ageing process (average \pm SD).

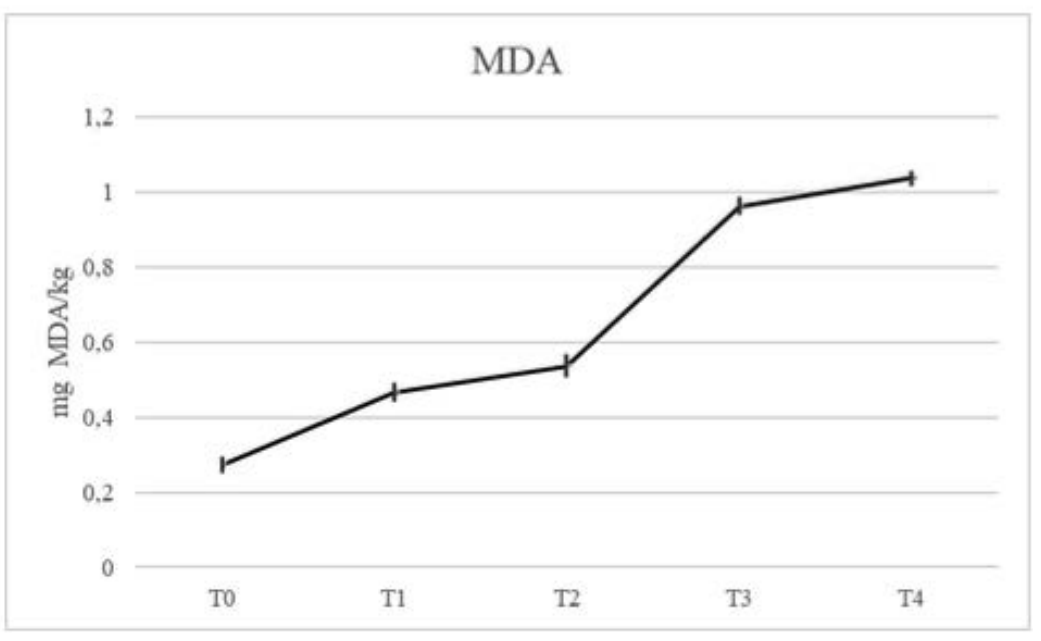

Figure 3. Trend of MDA during ageing process (average $\pm S D$ ). 
For all rheological analysis the steak cores were collected parallel to the muscle fibres, using a hand-held steel cork borer; c) Colorimetric assessment was performed by a Konica Minolta CR300 colorimeter (Minolta, Osaka, Japan) by CIE L*a* b* colour scale.

\section{Results}

\section{Physical-chemical analyses}

$\mathrm{PH}$ increased during ageing process (Figure 1). On the other hand, $\mathrm{a}_{\mathrm{w}}$ slowly decrease during the ageing process until T3: a sudden decline from 0.9629 to 0.9535 was observed (Figure 2). Figure 3 shows the trend of malondialdehyde (MDA) during ageing process.

Lipid oxidation increased slowly during the first sampling time of ageing process showing a sudden rise from T2 with values ranging between 0.273 and $1.036 \mathrm{mg}$ MDA/kg (Figure 3).

Table 1, according to Reg. UE 1169/11, show the nutritional values of beef during the ageing period.

\section{Microbiological analyses}

TBC and EB, showed a progressive decrease during ageing from $6.82 \log _{10}$ $\mathrm{CFU} / \mathrm{g}$ at $\mathrm{T} 0$ to $6.13 \log _{10} \mathrm{CFU} / \mathrm{g}$ at $\mathrm{T} 4$ (Figure 4) and from $2.58 \log _{10} \mathrm{CFU} / \mathrm{g}$ at T0 to $2.08 \log _{10} \mathrm{CFU} / \mathrm{g}$ at $\mathrm{T} 4$ (Figure 5), respectively. The yeast slightly increased during ageing from $4.6 \log _{10} \mathrm{CFU} / \mathrm{g}$ at $\mathrm{T} 0$ to $4.81 \log _{10} \mathrm{CFU} / \mathrm{g}$ at T4 (Figure 6). Only moulds showed a stable trend $\left(2 \log _{10}\right.$ $\mathrm{CFU} / \mathrm{g}$ from T0 to T4 - Figure 7).

No pathogens were found.

\section{Rheological analysis}

Coefficient of variation (CV) for instrumental parameters of TPA and WBSF profile during the meat maturation are showed in Table 2 (average values of $n .10$ test on $n$. 3 different steak).

Among TPA variables measured, friability and springiness showed the highest (148.75\%) and lowest $(11.43 \%)$ coefficient of variation respectively.

Particularly, the adhesiveness and the hardness showed the same trend: the values increased up to T4, with a low decrease at T3. Elasticity, cohesion and resilience result constant throughout the meat ageing. Conhesion and gumminess increased slowly until T3 showing only in the last interval values 3-4 times higher than the initial ones.

WBSF parameters decreased during ageing period, due to an increase in tenderness.

Concerning colour analysis L* decreased, reaching final values of 10.41 confirming meat darkening. The coordinates $a^{*}$ and $b^{*}$ showed the same behaviour: $a^{*}$ and $b^{*}$ values increased up to T2 and then showed a fluctuating trend. Considering the colour space CIE L*a*b* meat sample during maturation moved to the colour area coinciding with the red $\left(a^{*}\right)$ and yellow $\left(b^{*}\right)$ becoming significantly darker and slightly redder. This higher $b^{*}$ value could result from faster oxygenation on the fresh aged cut before a measurement was taken (Mac Dougall, 1977).

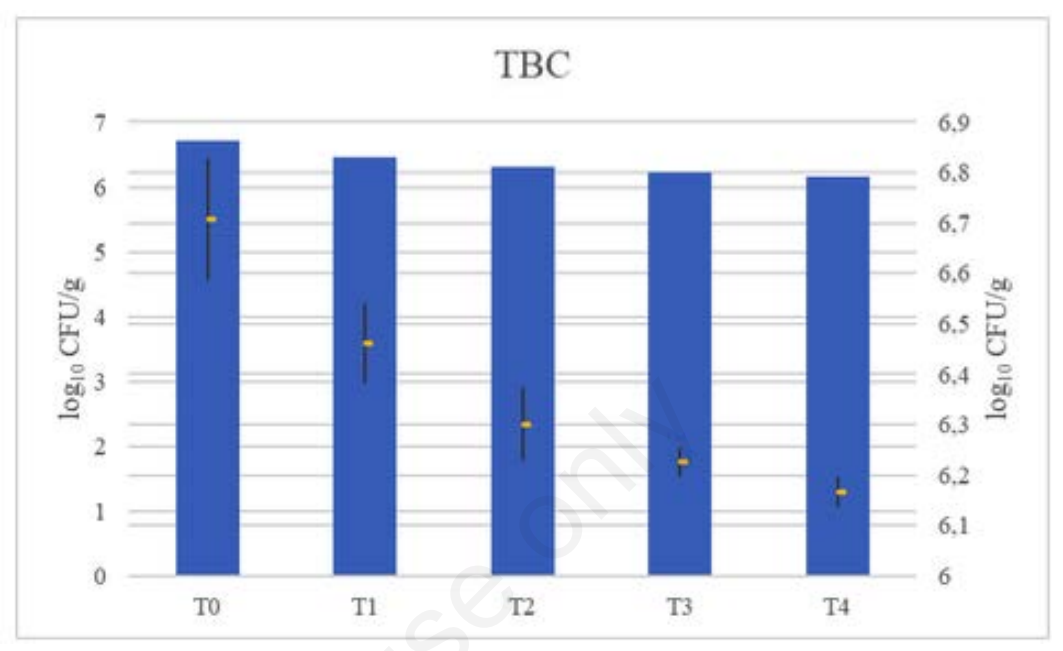

Figure 4. Total bacterial count $\left(\log _{10} \mathrm{CFU} / \mathrm{g} \pm \mathrm{SD}\right)$ of beef during the ageing period.

Table 1. Nutritional values of beef during the ageing period.

\begin{tabular}{|c|c|c|c|c|c|}
\hline \multirow{2}{*}{ Paramenters } & \multicolumn{5}{|c|}{ Average values - $100 \mathrm{~g}$} \\
\hline & T0 & $\mathrm{T} 1$ & $\mathrm{~T} 2$ & T3 & $\mathrm{T} 4$ \\
\hline Caloreis (Kcal) & 171,68 & 175,1 & 185,69 & 192,84 & 192,98 \\
\hline Proteins & 17,92 & 19,54 & 23,33 & 29,54 & 33.09 \\
\hline Carbohydrates & 0,25 & 0,52 & 0,66 & 0,76 & 0,81 \\
\hline Sugars & I & I & l & I & I \\
\hline Fat & 11 & 10,54 & 9,97 & 7,96 & 6,38 \\
\hline Saturated fat & 4,66 & 4,36 & 3,52 & 2,57 & 2,36 \\
\hline Sodium & 0,66 & 0,72 & 1,33 & 1,45 & 1,56 \\
\hline
\end{tabular}

Table 2. TPA and WBSF profile and coefficient of variation of during the meat maturation.

\begin{tabular}{lccc} 
Parameters & T0 & T4 & CV (\%) \\
Adhesiveness - TPA & -1.251 & -13.566 & 106.45 \\
Hardness - TPA & 10.025 & 41.478 & 70.03 \\
\hline Springiness - TPA & 0.653 & 0.660 & 11.43 \\
Cohesiveness - TPA & 0.425 & 0.295 & 20.11 \\
\hline Resilience - TPA & 0.110 & 0.114 & 40.68 \\
Cohesion - TPA & 1.910 & 5.390 & 57.13 \\
\hline Gumminess - TPA & 4.00 & 12.164 & 51.90 \\
Chewiness - TPA & 2.598 & 8.072 & 49.07 \\
\hline Friability - TPA & 0 & 18.856 & 148.75 \\
Peak force - WBSF & 29.4 & 5.64 & 72.45 \\
\hline Initial force - WBSF & 29.4 & 2.09 & 145.40 \\
Work - WBSF & 140.91 & 25.5 & 50.47 \\
\hline
\end{tabular}




\section{Discussion}

The initial $\mathrm{pH}$ can affect the improvement in tenderness: values detected in our work confirm result of Meat Export Federation of USA that found carcasses more tender with $\mathrm{pH}$ ranging between 5.4 and 5.7 (USMEF, 2014).

The $\mathrm{pH}$ and $\mathrm{a}_{\mathrm{w}}$ behaviour were similar to previous studies (Abram and Gaš, 2001; Dashdorj et al., 2016; Jayasooriya et al., 2007; Silva et al., 1999; Tapp et al., 2017). Final $\mathrm{pH}$ was different from values found by Velotto et al. (2015) in dry aged Marchigiana beef with a short period of maturation (25 days).

Aging method affected weight loss: in this work aged meat loose about $85 \%$ of its weight from T0 to T4 considering losing in moisture and trimming waste, higher than those found by Velotto et al. (2015).

Lipid oxidation generally increased during ageing period as already reported by Colle et al., (2015). However, in the present study MDA values never reached level higher than $1.03 \mathrm{mg} \mathrm{MDA} / \mathrm{kg}$ of meat, below the threshold value for rancidity of 2 $\mathrm{mg} \mathrm{MDA} / \mathrm{kg}$ (Watts, 1962). Since oxidation decreases calpain activity (Huff-Lonergan and Lonergan, 2005) the low levels of lipid oxidation detected may allow the calpains to stay active longer, so increasing tenderness thanks to the breakdown of muscle fibres caused by enzyme activity. According consumers opinion, the main characteristic to choose meat, besides tenderness, is colour (Renerre and Labas, 1987); unfortunately, meat subjected ageing process becomes darker. The darkening can be caused not only by lipid oxidation (Farouk et al., 1998), but also by changes in reducing ability, oxygen consumption rate, oxygen penetration depth, and myoglobin content (McKenna et al., 2005). In our study, even if oxidative processes are associated with discolouration of meat producing metamyoglobin by oxymyoglobin oxidation, low levels MDA reached at the end of process, contribute to a lower discoloration than natural meat ageing.

$\mathrm{CBT}$ and $E B$ are bacteria used to evaluate process hygiene criteria during food production process (Reg. EC 2073/05); The initial counts reflect the general meat microbiological status in relation to carcass handling, time of chilled storage and temperature control (Reid et al., 2017; Savell, 2008). In meat stored at refrigerated temperatures are manly composed by Pseudomonas, Brochothrix and Carnobacterium (Peruzy et al., 2019), common spoilage microorganism. In the present trial, the average TBC and $E B$ levels of the meat was lower to those report in other

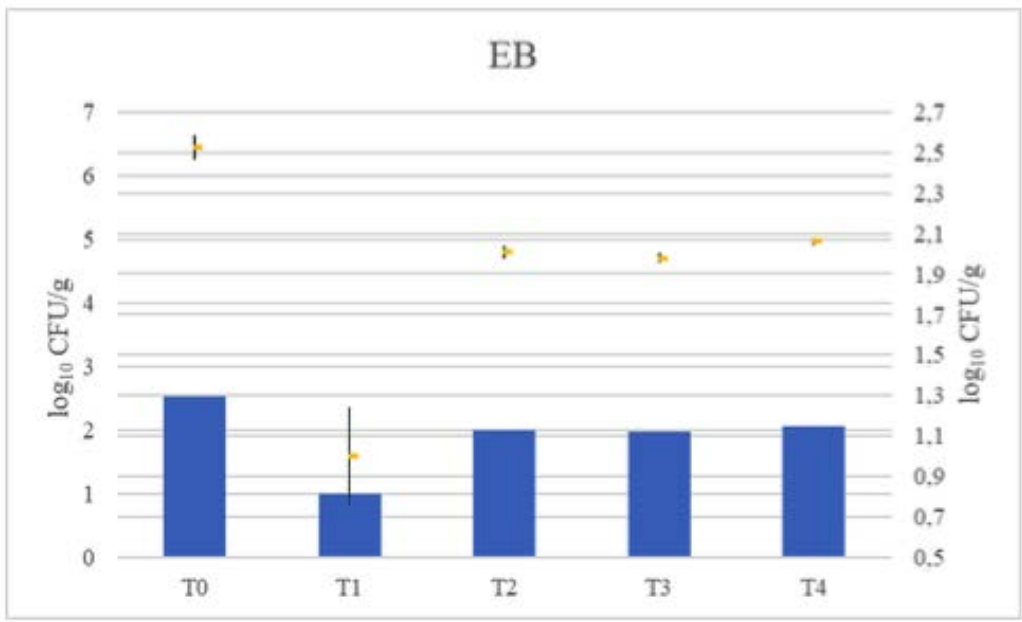

Figure 5. Enterobacteriaceae $\left(\log _{10} \mathrm{CFU} / \mathrm{g} \pm \mathrm{SD}\right)$ of beef during the ageing period.

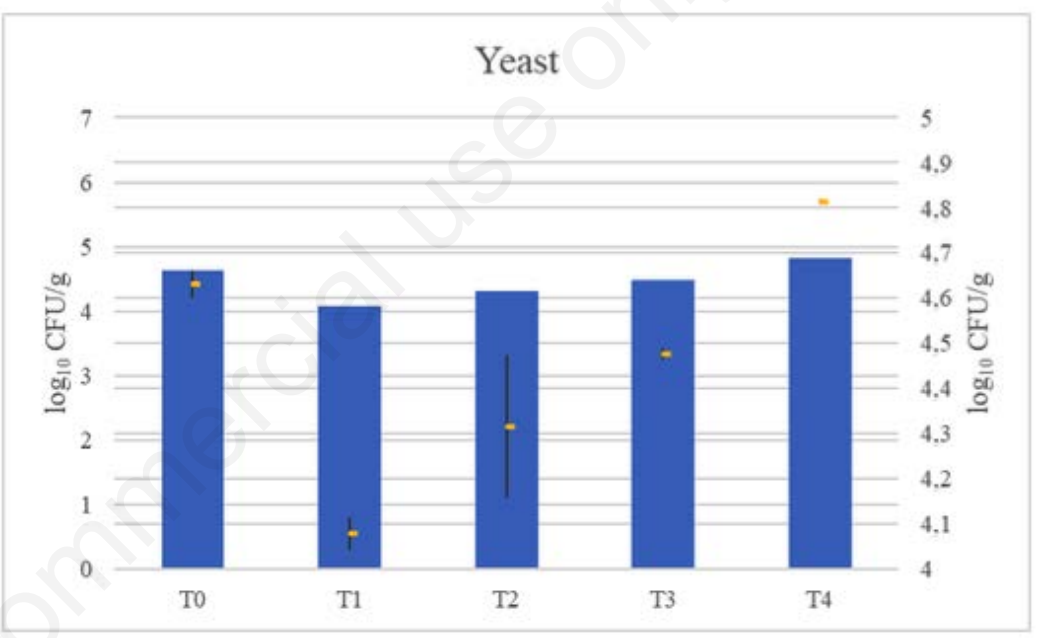

Figure 6. Yeast $\left(\log _{10} \mathrm{CFU} / \mathrm{g} \pm \mathrm{SD}\right)$ of beef during the ageing period.

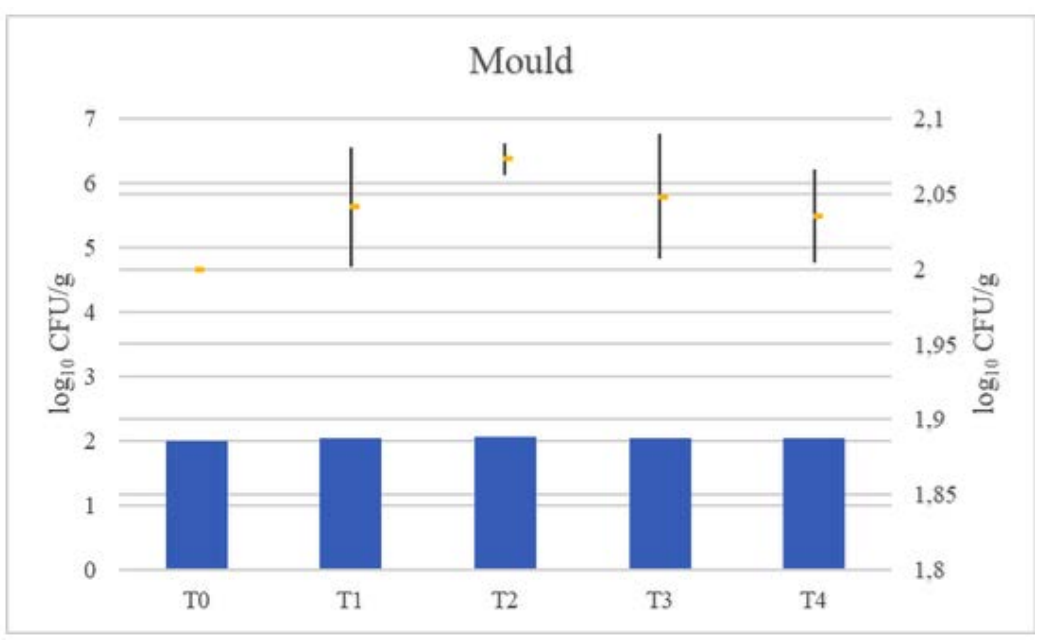

Figure 7. Mould $\left(\log _{10} \mathrm{CFU} / \mathrm{g} \pm \mathrm{SD}\right)$ of beef during the ageing period. 
studies (Chuku et al., 2016; Jahan and Siddique, 2015; Pennacchia et al., 2011) and showed a progressive slightly decrease during ageing in agreement to ; this result could be due to the ageing protocol applied $\left(\mathrm{T}^{\circ}\right.$ and $\mathrm{U}^{\mathrm{R}}$ ) and to the subsequently decrease of $\mathrm{a}_{\mathrm{w}}$ (Dashdorj et al., 2016). Yeast and mould count had no significative changes because these microorganisms can tolerate the low temperature and $\mathrm{a}_{\mathrm{w}}$; particularly, dry ageing encourages the growth of beneficial mould that could release proteases and create collagenolytic enzymes which break down the muscle and connective tissues bringing about tenderness and taste in the finished product (PrimeSafe).

Regarding the nutritional content, an increase in the content of proteins, $\mathrm{NaCl}$ and carbohydrates has been recorded, probably due to the weight-liquid loss during ageing with their concentration. Opposite behaviour for the fat content was recorded, probably due both to enzymatic lithic and oxidative processes (Dashdorj et al., 2016).

WBSF values were ageing time and $\mathrm{pH}-$ dependent as showed in different studies (Savell, 2008; USMEF, 2014). The increase in tenderness was linked to enzymatic hydrolytic activities during post mortem ageing (Savell, 2008; Spanier et al., 1997) by calcium-dependent hydrolases, calpain proteinases and cathepsins (Koohmaraie et al., 2006). In this study peak force (WBSF), linked to meat tenderness, showed a progressive decrease, as described by GeorgeEvins et al. (2004), to testify the greater tenderness achievement. Hardness had an increase during ageing period: this data demonstrates the surface drying.

\section{Conclusions}

The results of the present study indicate that extended ageing cause a remarkable weight loss but a limited lipid oxidation and an improvement in tenderness.

Starting from meat with a low CBT counts and checking the protocol of maturation parameters, it's possible to get a more tender aged meat with a light darkening, more pleasing to the consumer.

Aged beef represents for its characteristics a niche product and as such, besides standardizing procedures in terms of $\mathrm{U}^{\mathrm{R}}$, ventilation and $\mathrm{T}^{\circ}$, it is important to educate the consumer to this type of product.

Further research is needed to find a method to improve colour and to reduce the trimming waste of extended aged beef.

\section{References}

AOAC, 1990. Official Methods of Analysis, 15th ed. Method 950.46, 11, 931. Association of Official Analytical Chemists, Arlington, VA, USA.

AOAC, 2000. Official Methods of Analysis, 17th ed. Method 976.18. Association of Official Analytical Chemists, Gaithersburg, MD, USA.

Barton-Gade PA, Cross HR, Jones M, Winger RJ, 1988. In: H.R. Cross \& A.J. Overby (Eds.). Meat science, milk science and technology, pp. 141-171. Amsterdam: Elsevier Science Publishers B.V.

Beermann DH, 2009. ASAS centennial paper: A century of pioneers and progress in meat science in the United States leads to new frontiers. J Anim Sci 87:1192-8.

Bratcher CL, Johnson DD, Littell RC, Gwartney BL, 2005. The effects of quality grade, aging, and location within muscle on Warner-Bratzler shear force in beef muscles of locomotion. Meat Sci 70:279-84.

Chuku A, Etim LB, Obande GA, Asikong BE, Sani BE, 2016. Bacteriological Quality of Fresh Raw Beef and Chevon Retailed in Lafia Metropolis, Nigeria. J Microbiol Res 6:29-34.

Colle MC, Richard RP, Killinger KM, Bohlscheid JC, Gray AR, Loucks WI, Day RN, Cochran AS, Nasados JA, Doumit ME, 2015. Influence of extended aging on beef quality characteristics and sensory perception of steaks from the gluteus medius and longissimus lumborum. Meat Sci 110:32-9.

Dashdorj D, Tripathi K.,Cho S, Kim Y, Hwang I, 2016. Dry aging of beef; Review. J Anim Sci Technol 1:11.

De Geer SL, Hunt MC, Bratcher CL, Crozier-Dodson BA, Johnsond DE, Stika JF, 2009. Effects of dry aging of bone-in and boneless strip loins using two aging processes for two aging times. Meat Sci 83:768-74

Dixon CL, Woerner DR, Tokach RJ, Chapman PL, Engle TE, Tatum JD, Belk KE, 2012. Quantifying the "aging response" and nutrient composition for muscles of the beef round. J Anim Sci 90:996-1007.

Eilers JD, Tatum JD, Morgan JB, Smith GC, 1996. Modification of earlypostmortem muscle $\mathrm{pH}$ and use of postmortem aging to improve beef tenderness. J Anim Sci 74:790-8.

Farouk MM, Swan JE, 1998. Effect of rigor temperature and frozen storage on functional properties of hot-boned manufacturing beef. Meat Sci 49:233-47.
Field RA, Riley MC, Chang YO, 1971. Free amino acid changes in different aged bovine muscles and their relationship to shear values. J Food Sci 36:611-2.

Gašperlin L, Žlender B, Abram V, 2001. Colour of beef heated to different temperatures as related to meat ageing, Meat Sci 59:23-30.

George-Evins CD., Unruh JA, Waylan AT, Marsden JL, 2004. Influence of quality classification, aging period, blade tenderization, and endpoint cooking temperature on cooking characteristics and tenderness of beef gluteus medius steaks. J Anim Sci 82:1863-7.

Gruber SL, Tatum JD, Scanga JA, Chapman PL, Smith GC, Belk KE, 2006. Effects of postmortem aging and USDA quality grade on Warner-Bratzler shear force values of seventeen individual beef muscles. J Anim Sci 84:3387-96.

Grunert KG Bredahl L, Brunsø K, 2004. Consumer perception of meat quality and implications for product development in the meat sector - a review. Meat Sci 66:259-72.

Huff-Lonergan E, Lonergan SM, 2005. Mechanisms of water-holding capacity of meat: The role of postmortem biochemical and structural changes. Meat Sci 71:194-204.

Jahan F, Siddique AB, 2015. Bacteriological Quality Assessment of Raw Beef Sold in Sylhet Sadar. Agriculturists 13:9-16.

Jayasooriya SD, Torley PJ, Arcy BRD, Bhandari BR, 2007. Effect of high power ultrasound and ageing on the physical properties of bovine Semitendinosus and Longissimus muscles. Meat Sci 75:628-39.

Jennings TG, Berry BW, Joseph AL, 1978. Influence of fat thickness, marbling and length of ageing on beef palatability and shelf-life characteristics. J Anim Sci 46:658-65.

Koohmaraie M, 1996. Biochemical factors regulating the tougheninig and tenderization processes of meat. Meat Sci 43:193-S201.

Koohmaraie M, Geesink GH, 2006. Contribution of postmortem muscle biochemistry to the delivery of consistent meat quality with particular focus on the calpain system. Meat Sci 74:3443.

Lam F, 2013. Dry aged beef is a new trend in. Available from: http://www.bonappetit.com/test-kitchen/ingredients/article/dry-aged-beef-is-a-new-trend-inrestaurantsaround- the-country

Lepper-Blilie AN, Berg EP, Buchanan DS, Berg PT, 2012. Effects of post-mortem aging time and type of aging on flavor, 
tenderness, color, and shelf-life stability of beef loins with marbling between Slight to Small, Project summary. Available from: http://www.beefissuesquarterly.com/CMDocs/BeefResea rch/PE_Project_Summaries/FY11Effec t s _ of _ pos t - mortem _aging _ time_and_type.pdf

Mac Dougall DB, 1977. Colour in meat. In G. G. Birch, Sensory properties of foodNutrition and Food Science, 61:5-8 (pp. 59). London: Applied science publishers.

McKenna DR, Mies PD, Baird BE, Pfeiffer KD, Ellebracht JW, Savell JW, 2005. Biochemical and physical factors affecting discoloration characteristics of 19 bovine muscles. Meat Sci 700:66582.

Parrish FC Jr, Boles JA, Rust RE, Olson DG, 1991. Dry and wet aging effects on palatability attributes of beef loin and rib steaks from three quality grades. J Food Sci 56:601-3.

Pennacchia C, Ercolini D, Villani F, 2011. Spoilage-related microbiota associated with chilled beef stored in air or vacuum pack. Food Microbiol 28:84.93.

Perry N, 2012. Dry aging beef. Inter J Gastron Food Sci, 1:78-80.

Peruzy MF, Murru N, Yu Z, Cnockaert M, Joossens M, Proroga YTR, Houf K, 2019. Determination of the microbio- logical contamination in minced pork by culture dependent and $16 \mathrm{~S}$ amplicon sequencing analysis. Int $\mathrm{J}$ Food Microbiol 290:27-35.

PrimeSafe. Aging of Beef. Available from: https://www.primesafe.vic.gov.au/standards-and-guidelines/primenotes/ageing-of-beef/

Reid R, Fanning S, Whyte P, Kerry J, Lindqvist R,Yu Z, Bolton D, 2017. The microbiology of beef carcasses and primals during chilling and commercial storage. Food Microbiol 61:50-57.

Renerre M, Labas R, 1987. Biochemical factors influencing metmyoglobin formation in beef muscles. Meat Sci 19:151-65.

Ruiz de Huidobro F, Miguel E, Blazquez B, Onega E, 2005. A comparison between two methods (Warner-Bratzler and texture profile analysis) for testing either raw meat or cooked meat. Meat Sci 69:527-36

Savell JW, 2008. Dry-aging of beef, executive summary. National Cattlemen's Beef Association. Available from: http://www.beefresearch.org/cmdocs/be efresearch/dry\%20Aging\%20of\%20bee f.pdf

Silva JA, Patarata L, Martins C, 1999. Influence of ultimate $\mathrm{pH}$ on bovine meat tenderness during ageing. Meat Sci 52:453-9.
Spanier AM, Flores M, McMilli KW, Bidne TD, 1997. The effect of post-mortem aging on meat flavor quality in Brangus beef. Correlation of treatments, sensory, instrumental and chemical descriptors. Food Chem 59:531-8.

Tapp WN, Christjohn CT, Griffing DA, Bratcher CL, 2017. Evaluation of meat quality on high $\mathrm{pH}$ strip loins injected with buffered acetic acid. Meat Muscle Biol 1:218-226

USMEF, Meat Export Federation of USA, 2014. Guidelines for U.S. dry aged beef for international markets. 2014. https://www.usmef.org/guidelines-foru-sdry-aged-beef-for-international-markets/

Velotto S, Pagano F, Barone CMA, Esposito M, Civale G, Crasto A, 2015. Effect of aging technologies on some qualitative characteristics of Longissimus dorsi muscle of Marchigiana beef. Agron Res 13:1143-51

Watts BM, 1962. Meat products A. Day, R.P.R. Smuhulber (Eds.), Symposium on food: Lipids and their oxidation, AVI Publ. Co, Westport 1962, pp. 202-219

Xiong YL, Gower MJ, Li C, Elmore CA, Cromwell GL, Lindeman MD, 2006. Effect of dietary ractopamine on tenderness and postmortem protein degradation of pork muscle. Meat Sci 73:600-4. 